\title{
The methylic versus the ethylic route: considerations about the sustainability of Brazilian biodiesel production
}

\author{
Alexandre Bevilacqua Leoneti ${ }^{1}$ - Valquiria Aragão-Leoneti ${ }^{2}$ • \\ Simone Vasconcelos Ribeiro Galina ${ }^{1}$ - Geciane Silveira Porto ${ }^{1}$
}

Received: 30 April 2015/Accepted: 29 December 2015/Published online: 9 January 2016

(C) Springer Science+Business Media Dordrecht 2016

\begin{abstract}
Brazil is considered one of the world's leading producers of biofuels given the predominance of ethanol fuel in its energy matrix. However, despite the prominence of Brazil in ethanol production, the vast majority of biodiesel production plants in Brazil use methanol instead of ethanol as the alcohol for transesterification reaction, as is generally the case in the rest of the world. The aim of this paper is therefore to examine the transesterification process in the Brazilian biodiesel production in terms of sustainability. In this regard, it was necessary to evaluate the way in which the industrial process is currently carried out, the role of government incentives or subsidies for the use of ethanol to produce biodiesel, and the investments of companies in technology development for the same purpose. This study presents indications that the development of the biodiesel market in Brazil is still oriented toward a production model which is inconsistent with the environmental and social aspects of sustainability.
\end{abstract}

Keywords Biodiesel $\cdot$ Transesterification $\cdot$ Methanol $\cdot$ Ethanol

Alexandre Bevilacqua Leoneti

ableoneti@usp.br

Valquiria Aragão-Leoneti

varagao@iq.unesp.br

Simone Vasconcelos Ribeiro Galina

svgalina@usp.br

Geciane Silveira Porto

geciane@usp.br

1 School of Economics, Business Administration and Accounting (FEARP/USP), Bandeirantes Ave., 3900, Ribeirão Preto/SP, CEP 14040-900, Brazil

2 Institute of Chemistry (IQ/UNESP), Francisco Degni St., 55, Araraquara/SP, CEP 14800-900, Brazil 


\section{Introduction}

Biodiesel is an environmentally friendly fuel that can be obtained by means of different processes of transesterification (Demirbas 2005). According to Ma and Hanna (1999), the most common process for biodiesel production is the catalytic transesterification method, which is the reaction between animal fat or vegetable oil and alcohol (methanol or ethanol), in the presence of a catalyst. This process aims to modify the molecular structure of vegetable oil and animal fat, giving them similar physicochemical properties to those of diesel fuel (Basha et al. 2009; Girard and Fallot 2006).

Brazil is considered one of the world's leading producers of biofuels given the predominance of ethanol fuel in its energy matrix (Lôbo et al. 2009). However, despite the prominence of Brazil in ethanol production, the vast majority of biodiesel production plants in Brazil use methanol instead of ethanol as the alcohol for transesterification reaction, as is generally the case in the rest of the world (Janaun and Ellis 2010; Renó et al. 2011; ANP 2014).

According to Olah (2005), methanol is mainly obtained by methane oxidation, and it is considered non-renewable and of higher toxicity than ethanol (Pereira and Andrade 1998; Quintella et al. 2009). Brazil suffers from the disadvantage of not being self-sufficient in its production, having to import it for this purpose (Rathmann et al. 2012). In contrast to methanol, ethanol is renewable and biologically less harmful to the environment (Demirbas 2005, 2008; Kaercher et al. 2013). Moreover, Brazil is able to produce ethanol at a volume that is capable of meeting the biodiesel production (ANP 2013; Brazil 2015).

There are perhaps two main reasons why the methylic route has become the method of preference in Brazil: firstly because the ethylic route has not been completely mastered-a technological lack (Rovere et al. 2011) — and secondly because the cost of production using methanol is usually lower than that of ethanol—an economic disadvantage (Kanitkar et al. 2011). On the other hand, there are social problems connected to the use of methanol, especially regarding its high toxicity and greater environmental impacts when compared with ethanol (Frenia and Schauben 1993; Pereira and Andrade 1998; Quintella et al. 2009; Leoneti et al. 2012).

The present disadvantages of the ethylic route could eventually be overcome by means of new technological process (Quintella et al. 2009). A great deal of research has been carried out on ways to improve ethanolysis for biodiesel production (Stamenkovic et al. 2011; Yusoff et al. 2014), focusing on the following four possible methods for biodiesel production, namely: using an alkali catalyst, using an acid catalyst, using a lipase catalyst and by supercritical fluid reaction (Marchetti et al. 2007).

For example, the ethanolysis reaction of different oils has been investigated by changing the reaction conditions and developing new catalytic systems and processes (Stamenkovic et al. 2011). Pedersen et al. (2014) investigated bath biodiesel production by means of enzymatic catalysis using a liquid lipase formulation that increased the rate and the conversion of the ethanolysis reaction. In addition, microwave irradiation has been used to improve the results of the ethylic route, thus increasing its efficacy in comparison with the conventional method of biodiesel production that uses methanol (Kanitkar et al. 2011). In the same direction, Da Rós et al. (2014) proposed an enzymatic approach to the synthesis of biodiesel by means of the use of an ethanolysis reaction using microwave irradiation. Kaur and Ali (2015) developed an efficient and stable catalyst of molybdenum impregnated calcium oxide in order to carry out ethanolysis. Vieitez (2008) investigated different supercritical reaction conditions and reported that the effect of temperature and substrate 
flow rates strongly affected the conversion reaction. Mendow et al. (2012) demonstrated a further way to achieve better performance in biodiesel production by means of the purification of the ethyl ester. Finally, Mendow and Querini (2013) proposed a methodology for the purification of crude biodiesel with extensive soap content.

Furthermore, several recent studies have focused on the sustainability of biodiesel production in several parts of the world (Janssen and Rutz 2011; Jayed 2009). There have also been specific studies in Brazil considering the environmental aspect of biodiesel production (Castanheira et al. 2014) and others focusing in its economic, social and technical sustainability (Rathmann et al. 2012). However, little research has been carried out on the comparative merits of the methyl and ethyl routes with regard to sustainability.

The aim of this paper is therefore to examine the transesterification process in the Brazilian biodiesel production in terms of sustainability. In this regard, it was necessary to evaluate the way in which the industrial process is currently carried out, the role of government incentives or subsidies for the use of ethanol to produce biodiesel, and the investments of companies in technology development for the same purpose. With this in mind, the aim of this research was both to evaluate the current method of biodiesel production in Brazil and to consider viable ways to carry out the production through a truly sustainable route.

\section{Method}

The present study is an exploratory investigation that aims to describe the production process of biodiesel in Brazil in order to discuss the sustainability of the process using the available technology. The research was conducted as follows. Firstly, an investigation was carried out using Brazilian secondary data sources (governmental reports, newspapers, magazines, books and Web sites) in order to ascertain which route has been in use for biodiesel production among the 67 current operating facilities in Brazil. Next, bibliographical research was conducted in national and international journals using keywords such as biodiesel, production, transesterification, methanol and ethanol in order to compare the advantages and disadvantages of using either the methylic or the ethylic route in biodiesel production.

In parallel, another investigation was carried out into the existence of incentives for the development of new technology to produce biodiesel in Brazil. Initially, two calls for projects related to biodiesel production from the National Fund for Scientific and Technological Development-FINEP - were evaluated. Next, a case study was conducted in a company named Fertibom ${ }^{1}$ using interview and secondary data. Finally, a patent search was carried out using the Espacenet Web site (Espacenet 2013), with the aim of evaluating Brazilian companies as players on the world stage of technology for biodiesel production using ethanol. In total, 114 patents were analyzed from more than 90 countries all over the world, including Brazil. The keywords used to identify the innovation were ethanol and transesterification, in the fields "abstract" and "title" in the patents.

\footnotetext{
${ }^{1}$ Fertibom Industries Ltd is the largest scale Brazilian Biodiesel producer that uses the ethylic route.
} 


\section{Results and discussion}

\subsection{Biodiesel production in Brazil}

Brazil is considered an important global player in biofuel production (Howarth et al. 2009). This is largely due to its production of ethanol fuel, which has been incorporated into the energy matrix since the launch of the Pro-Alcohol Program. ${ }^{2}$ Like ethanol production, the National Program for the Production and Use of Biodiesel-PNPB (Stattman et al. 2013; ANP 2011a) - is another Brazilian program, which also aims to increase the share of renewable energy sources in the Brazilian energy matrix. The primary objective of both projects was the reduction of dependence on non-renewable fuels and to reduce the net trade balance by using a renewable fuel, mainly to circumvent international oil crises (ANP 2011a; Garcia et al. 2007; Rathmann et al. 2012). Table 1 shows the development of biofuels in Brazil, highlighting the periods of global oil crises and the launching of government programs.

The introduction of biodiesel into the national energy matrix was possible due to the Law 11,097, from January 2005. Figure 1 shows the lack of biodiesel production in Brazil before (2005) (when the above Law was enacted) as well as the significant increase in volume in 2008, the start date of the addition of biodiesel to regular diesel.

Nine years after its implementation, biodiesel production is not uniformly distributed in the country. The principal region producer is the Midwest, which accounts for almost $39 \%$ of national production. The Midwest is followed by the Southern region, which accounts for $35 \%$ of the overall production. The third biggest producer region is the Southeast, followed by the Northeast and the Northern, which account for 17, 5 and $4 \%$ of the overall production, respectively (ANP 2013). This difference between the regions can be explained by the distribution of the principal raw material crop, namely the soybean.

The use of soybean, despite affecting negatively the food market as noted by Rathmann et al. (2012), is the principal feedstock for biodiesel production in Brazil, accounting for $86.2 \%$ of the main raw materials in use (ANP 2011b), and about $32 \%$ of the total domestic consumption of the soybean (Castanheira et al. 2014). Among other factors that could explain the use of this feedstock, it is important to point out that: (1) for large production capacities, typically above 300 tons per day of raw material, it is necessary to use oilseeds with a low oil content-less than $25 \%$ - as in the case of soybeans (Parente 2003); (2) for biodiesel production on a large scale, it is necessary to consider the strategic aspects of planting the grain, such as seasonality, productivity and culture risk, which is the case of the soybean (Khalil 2006); and (3) there needs to be a close proximity between the sources and the biodiesel plants, especially in Brazil given its huge territory (Leoneti et al. 2012).

Not surprisingly, the distribution of soybean production in the country is closely linked to the production of biodiesel, with the Midwest, the largest producer region, accounting for $46 \%$ of the total production, followed by the Southern, with $38 \%$, the Northeast $(8 \%)$, the Southeast $(6 \%)$ and the Northern, with only $2 \%$ of the total production. A Chisquared nonparametric hypothesis test cannot reject the hypothesis that these two samples have the same distribution with $p$ value equal to 0.11 , corroborating the affirmation that the

\footnotetext{
2 The Pro-Alcohol Program was a successful Brazilian government program of petroleum large-scale substitution. It was developed to avoid dependence on foreign petroleum replacing a non-renewable fuel for ethanol fuel made from sugarcane.
} 
Table 1 Development of biofuels in Brazil and the global crude oil prices market
Source: Adapted from ANP (2011a), Garcia et al. (2007), EIA (2014), and Brazil (2015)

Fig. 1 Biodiesel annual production in Brazil (in $\mathrm{m}^{3}$ ). Source: ANP (2014)

\begin{tabular}{ll}
\hline Year & Event \\
\hline 1925 & Tests adding ethanol to petrol \\
1938 & Law 737 requires $2 \%$ addition of ethanol to petrol \\
1974 & First global crude oil crisis (price increase significantly) \\
1974 & Launch of Pro-Alcohol \\
1977 & 4.5\% ethanol addition to petrol \\
1979 & 15\% ethanol addition to petrol \\
1980 & Second global crude oil crisis (price increases significantly) \\
1980 & The first Brazilian biodiesel patent \\
1983 & Ethanol cars represent 90 of total sales \\
1985 & Crude oil prices decrease significantly in the world \\
1985 & 22\% ethanol addition to petrol \\
2003 & Initial sales of Flexible-Fuel Vehicles \\
2005 & Launch of PNPB \\
2007 & Third global crude oil crisis (price increases significantly) \\
2008 & $2 \%$ biodiesel addition to diesel \\
2008 & Ethanol consumption matches petrol consumption as fuel \\
2010 & $5 \%$ biodiesel addition to diesel \\
2015 & $27 \%$ ethanol addition to petrol \\
\hline
\end{tabular}

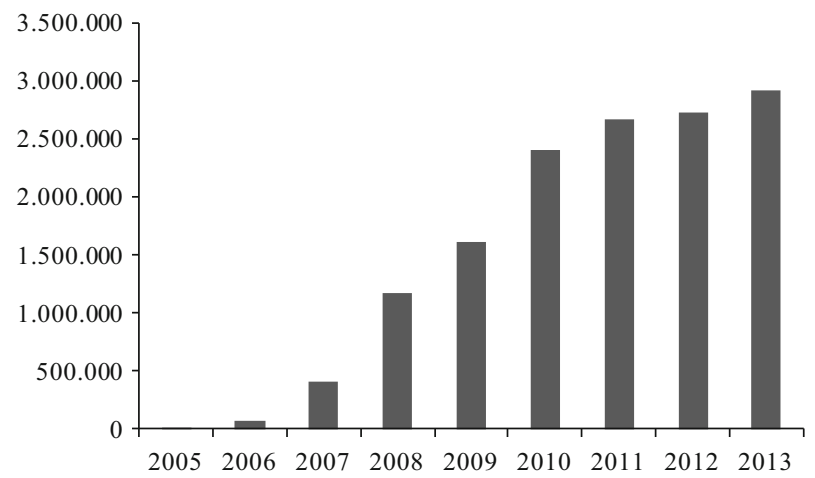

larger the soybean production, the bigger the biodiesel production. Figure 2 presents the Brazilian regions and their respective amount of overall biodiesel and soybean production.

It is worth noting that besides promoting the inclusion of biodiesel into the Brazilian energy matrix, the other PNPB main guidelines are: (1) promoting social inclusion, (2) ensuring competitive prices, quality and supply and (3) producing biodiesel from different oil sources to strengthen regional potential for feedstock production (ANP 2011a). Regarding the social aspects of using the soybean as the principal feedstock, Rathmann et al. (2012) noted that biodiesel production has not yet reached the goal of promoting regional development through the inclusion of family farmers into the feedstock supply chain, given that biodiesel is produced with raw material (mainly soybean) acquired from big producers. 


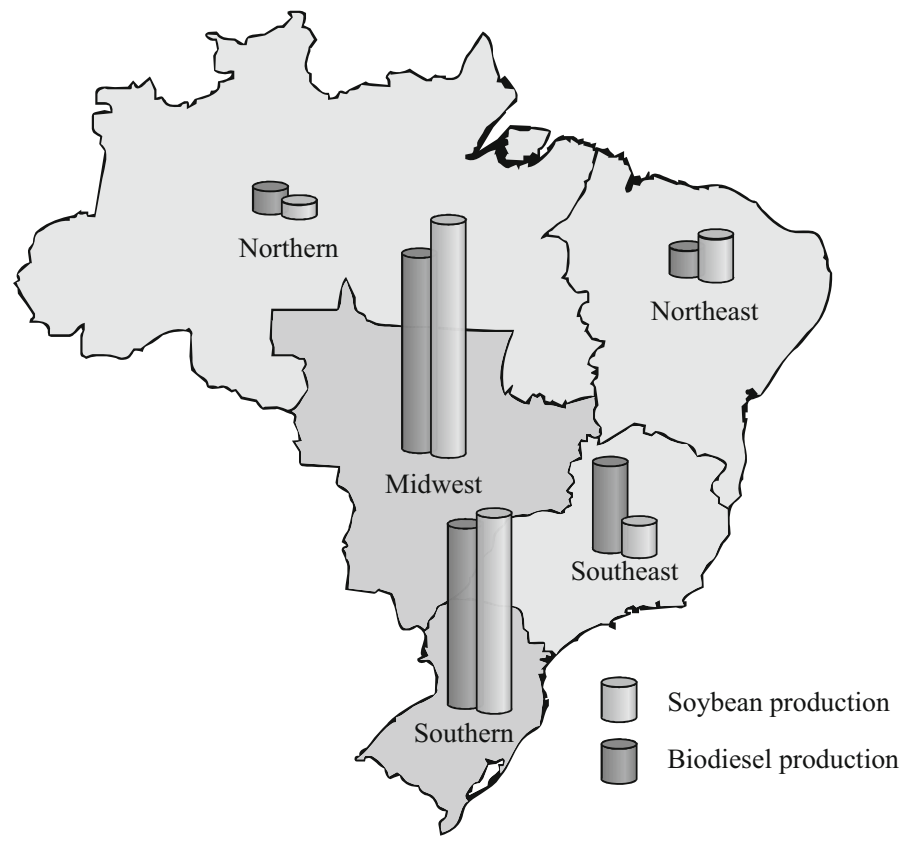

Fig. 2 Biodiesel and soybean production in Brazilian regions (as a share of the total production). Source: ANP (2013) and ANP (2011b)

Other economic, environmental, social and technical impacts of biodiesel production in Brazil are discussed in Rathmann et al. (2012), Castanheira et al. (2014), Garcez and Vianna (2009), Kanitkar et al. (2011) and Rovere et al. (2011). However, little research has been carried out on the comparative merits of the methyl and ethyl routes with regard sustainability.

\subsection{Methanol versus ethanol in the Brazilian biodiesel production}

Despite its environmental benefits and the fact that ethanol is produced abundantly in Brazil, the current scenario of biodiesel production in the country consists largely of biodiesel producers that use methanol instead of ethanol in the transesterification biodiesel process. Figure 3 shows the capacity for biodiesel production in Brazil in July 2009, and the production process adopted. It can be observed that in almost all production plants (59 out of 65), the production was designed to produce biodiesel through the methylic route. ${ }^{3}$

It is worth to observe that the plants that processed biodiesel in 2009 through the ethylic route were small, many of them pilot plant size. In these small plants, the process takes place in batches, a procedure that allows the removal of ethanol from the final product, thus minimizing losses and allowing a reduction in production costs (Quintella et al. 2009). Even in plants designed to operate both ethylic and methylic routes, the sizes of the plants in general are small. This scenario changed between 2009 and 2014, during which period the overall production capacity doubled, mainly due to the increase in production through

\footnotetext{
3 The plants which were designated to produce biodiesel by methylic or ethylic route were performing only through methylic route, counting only for the methylic route type.
} 


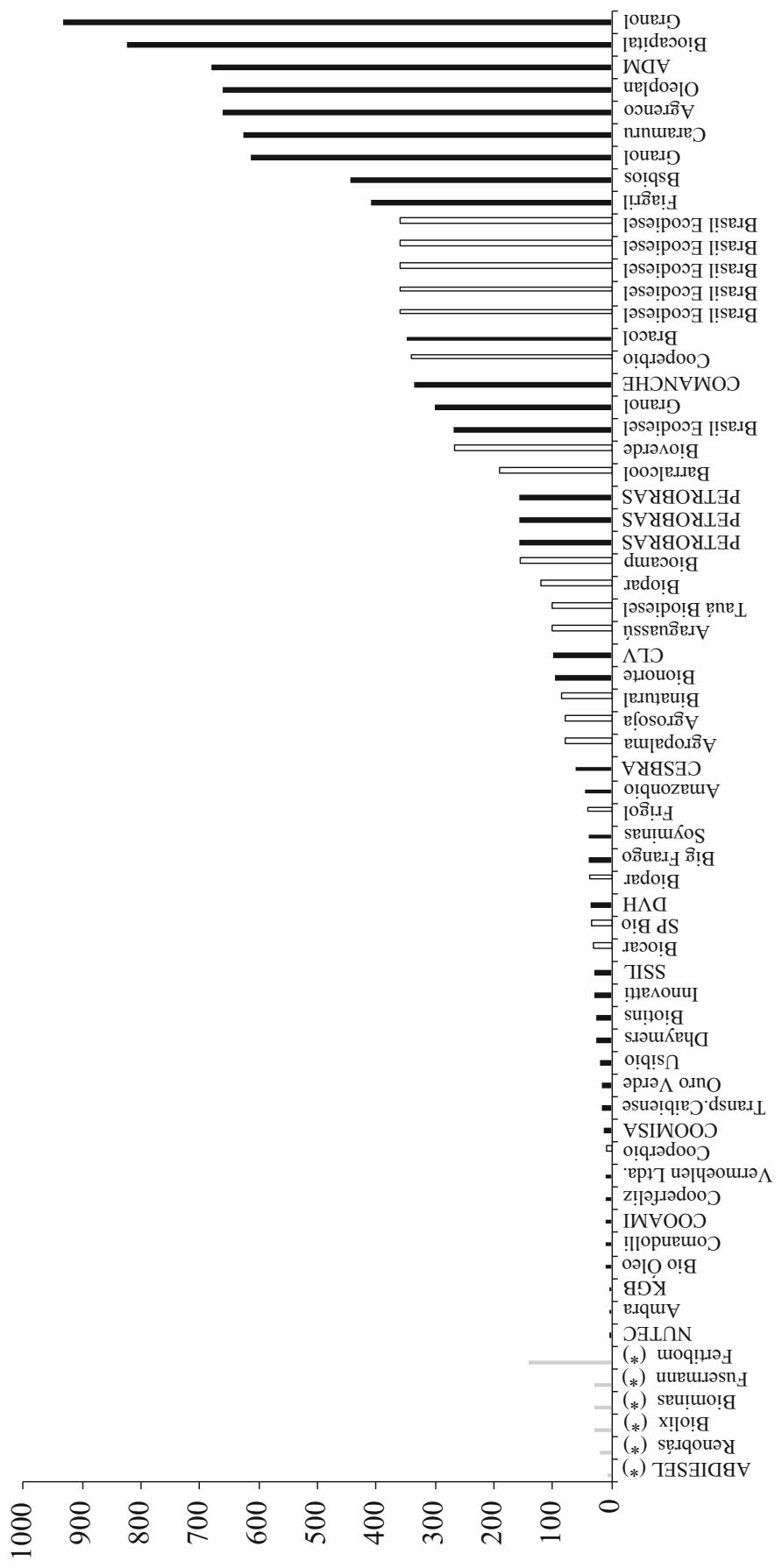


the methylic route (ANP 2014). Meanwhile, the plants which were able to produce biodiesel only through the ethylic route, such as Abdiesel, Biolix, Biominas, Fusermann and Renobrás, either changed to the methylic route, e.g., Abdiesel, or ceased their activities, as was the case with companies such as Biolix, Biominas, Fusermann and Renobrás. This leaves Fertibom Industries Ltd in Catanduva, São Paulo state, the only utility that produces biodiesel through the ethylic route on a large scale.

\subsubsection{Production of biodiesel by ethylic route at Fertibom Industries Ltd}

It is worth analyzing closely the case of Fertibom because this company, despite being the only Brazilian company to compete in the market by exclusively using ethylic transesterification, has invested in R\&D to improve this technological route. Fertibom, which is generally considered to be the first company to produce biodiesel in the state of Sao Paulo, developed its own production process and adopted procedures for biodiesel production using the ethylic route from various oilseeds and animal fats (Fertibom 2015). The company is a pioneer in the production of ethyl biodiesel on a commercial scale in the country. Fertibom has the largest capacity for biodiesel production using the ethanol route in Brazil; in 2011 , it produced about 31 thousand $\mathrm{m}^{3}$ of biodiesel that represented, approximately, $1.2 \%$ of the national production. According to the CEO of the company, Fertibom's preference for the production of biodiesel by the ethylic route was motivated primarily by their commercial relationship with alcohol mills, which were their main clients before the company entered into the biodiesel business. Starting out with just a pilot plant, biodiesel was eventually produced on an industrial scale, always using ethanol as a reagent; this highlights the fact that during this period there were times when ethanol had become more economically viable than the methanol used in the methylic route.

The technology developed by Fertibom to produce biodiesel by the ethylic route is called Biomax, and it uses a specific transesterification process called T-Max (Fertibom 2015). This technology was first developed in 2003 and is seen by the company as a great accomplishment. In terms of the technology developed, the company states that industrial secrecy was chosen as a technology protection strategy because further developments were needed before requesting patents (FINEP 2015). On the other hand, Fertibom did not reveal how much it had invested in the development of the technology as the CEO states that "this question of funds pales before the process," although it has been publicly acknowledged that the money invested by FINEP in the two projects amounted to a total of R $\$ 1.3$ million from 2001 to 2008.

However, it seems likely that Fertibom developed its particular process of producing biodiesel due to the presence of ethanol producers in its very specific supply chain, which is not the case with most the companies launched with the specific goal of producing biodiesel. This is because Fertibom is located in the biggest ethanol production region in Brazil, the Southeast, which is also not the case with the other producers.

\subsubsection{The option for the methylic route in Brazil: sustainable aspects}

Some technical and economic advantages could be identified as possible reasons for the choice of the methylic route in Brazilian production. Firstly, from an economic point of view, there is the fact that the price of ethanol is generally higher than the price of methanol to the producers (Demirbas 2005; BNDES 2008; Sanli and Canakci 2008; Kanitkar et al. 2011; BIODIESELBR 2014). Moreover, there are other factors related to operational performance which could reduce the production costs, namely: (1) the fact that 
methanol consumption in the transesterification process is approximately $35 \%$ lower (Sanli and Canakci 2008; Quintella et al. 2009; Nogueira 2011); and (2) the fact that the reaction time through the methylic route is more than halved when using ethanol (Sanli and Canakci 2008; Khalil 2006). These cost reductions could be seen as economic advantages.

In addition, there are arguably other reasons why it is technologically advantageous, for example: (1) the technology for producing biodiesel by the methylic route is at an advanced state, which is not the case with the production of biodiesel by the ethylic route (Lima 2004; Hall et al. 2009; Rovere et al. 2011); (2) methanol reduces the difficulty of separating biodiesel from glycerol (Meher et al. 2006; Haas et al. 2006; Boog et al. 2011); and (3) the methylic route provide non-extensive soap formation-about 3 times lowerwhen compared with ethanol under similar conditions (Mendow et al. 2012). These factors are pointed out by several engineers and traders that operate in the biodiesel production industry and could explain the preference for the methylic route over the ethylic route (Garcez and Vianna 2009).

However, it is important to stress that methanol also presents disadvantages over ethanol especially regarding its environmental and social impact. As stated by Kaercher et al. (2013), if methanol is allowed to escape in the biodiesel production, the estimated physical, environmental and social impacts associated with biodiesel production by the ethanol-based route would be less negative than those produced by using methanol. It is also worth mentioning that the use of ethanol provides non-toxic glycerol that could be used in animal feeding, which would largely solve the problem of the surplus of the byproduct glycerol in biodiesel production (Leoneti et al. 2012). In terms of greenhouse gas emissions, according to Sheehan et al. (1998, p. g13), at the tailpipe, biodiesel (most of which is renewable) emits $4.7 \%$ more $\mathrm{CO}_{2}$ than petroleum diesel due to its non-renewable portion of methanol. In addition, as noted by Gui et al. (2009), the non-renewable sources, including methanol, might cause supply and cost uncertainties.

With specific regard to the social impact, Frenia and Schauben (1993) and Pereira and Andrade (1998) have noted that daily short exposures to methanol vapors can result in an accumulated concentration which is severe enough to cause damage to the health. The high toxicity of methanol compared to ethanol can be evaluated by checking industrial recommendations for product handling. According to the United Nations Globally Harmonized System - GHS — for dangerous substance directives, methanol has highly flammable vapors, is toxic if swallowed, in contact with skin or inhaled, and might cause damage to organs. Ethanol, by contrast, has highly flammable vapors and might cause eye irritation (EU 2008).

When used in biodiesel production, traces of methanol remain in the glycerol, which are eventually used as a supplement in animal feed (Leoneti et al. 2012). According to Yusoff et al. (2014) traces of methanol are highly undesirable in the food chain because methanol is metabolized in life-bodies into formaldehyde (an extremely hazardous compound) and subsequently formic acid, while ethanol is metabolized into acetaldehyde then quickly into acetic acid, as shown in Fig. 4.

Moreover, Brazil needs to import almost all the methanol employed in the biodiesel production process (SIDRA 2014; ALICEWEB 2014; Rathmann et al. 2012). There are only two Brazilian companies competing in the methanol market: GPC Chemistry of Rio de Janeiro, with a capacity of 220 thousand tons, and Petrochemical Company (Northeast Copenor), with 82 thousand tons. The Chilean Methanex is the third largest competitor in the national market and is the global leader in the manufacturing and marketing of methanol (BIODIESELBR 2014). According to Methanex, in some periods during 2012, Brazil was able to import only $10-15 \%$ of the volume of methanol needed due to problems 
(a)

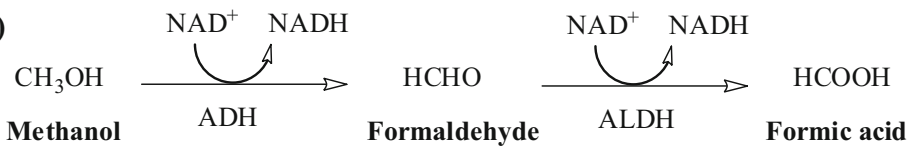

(b)

$\mathrm{CH}_{3} \mathrm{CH}_{2} \mathrm{OH}$

Ethanol

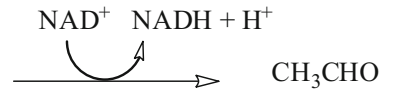

$\mathrm{ADH}$

Acetaldehyde

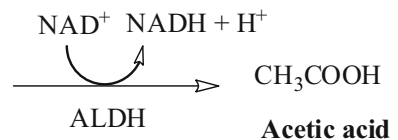

Fig. 4 Metabolic pathway involved in a methanol and $\mathbf{b}$ ethanol metabolism. Source: Adapted from Yusoff et al. (2014)

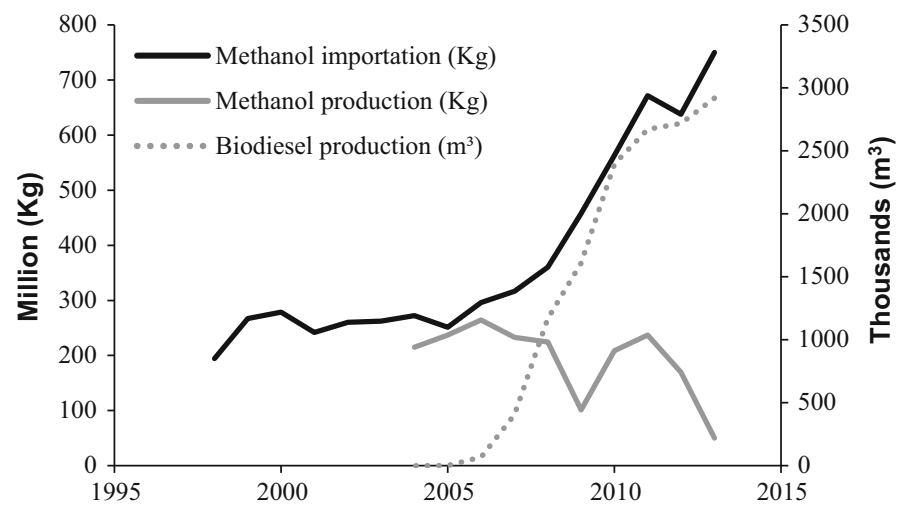

Fig. 5 Methanol importation and production $(\mathrm{Kg})$ versus biodiesel production $\left(\mathrm{m}^{3}\right)$ in Brazil. Source: ALICEWEB (2014), SIDRA (2014)

in Brazilian docks. At the beginning of 2013, due to methanol shortages, the government decided to reduce to zero the tax rate on methanol importation, which was prorogated for the year of 2014 (MDIC 2014).

Figure 5 depicts the increase, in kilograms, of methanol imported since the launch of PNPB (black line, left axis), the decline of methanol production in Brazil (gray line, left axis) and the production, in cubic meters, of biodiesel in the country (gray dotted line, right axis). It is possible to see, from Fig. 5, the problem of importation in the year of 2012 (the negative peak during the year 2012) and the Brazilian methanol production deficiency in contrast to biodiesel production.

In economic terms, the importation of methanol has reduced the benefits of biodiesel production. According to Rathmann et al. (2012), one of the justifications for implementing the PNPB given by the Brazilian Government was to improve the trade balance, in order to reduce dependence on imported non-renewable fuels, including diesel. The authors have found that, considering the importation of methanol to produce biodiesel in 2009, there was a net trade deficit of about US\$ 37 million, compared to the saving of money avoided by replacing diesel imported with biodiesel. In this respect, McBride et al. (2011) state that domestic bioenergy systems would be safer and more sustainable than imported fossil fuels, which could be seen as an advantage of using ethanol in the biodiesel process. 


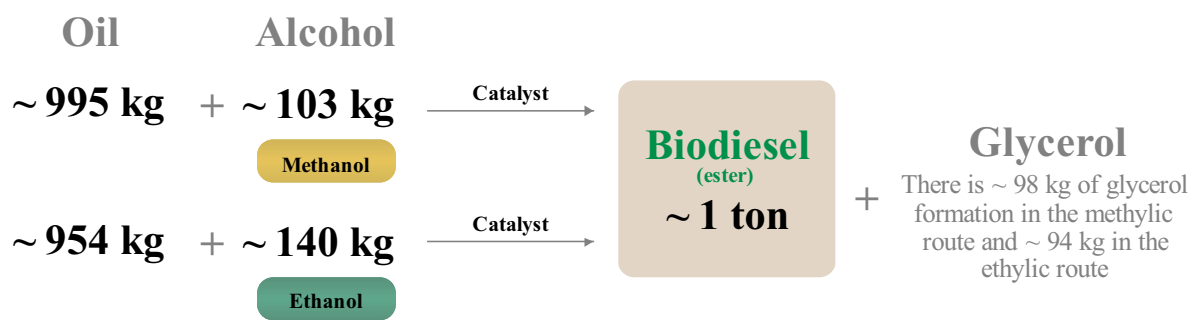

Fig. 6 Biodiesel process production by the methylic and ethylic routes. Source: Parente (2003)

Therefore, ethanol brings environmental and safety benefits (Kanitkar et al. 2011) and has the advantage of being renewable, non-toxic and biodegradable (Demirbas 2005). There is also the fact that Brazil annually produces about 12 million cubic meters of ethanol from sugar cane (ANP 2013). If Brazil used ethanol in the transesterification process, it would only need about 350 thousand cubic meters ( $3 \%$ of the total production) to meet the needs of almost 4 million cubic meters of biodiesel produced annually, an amount that could be eventually obtained from the reduction of ethanol/petrol blend percentage, currently around $27 \%$ (Brazil 2015).

Howarth et al. (2009) state that Brazil is very competitive in terms of ethanol production. An example of this is the strategic interest in Brazilian sugar cane production by the U.S. company Amyris, holder of the manufacturing process of Farnesene. Farnesene is a hydrocarbon molecule that can be used for a wide range of products varying from cosmetics, perfumes and detergents to diesel production and which has a similar performance to that of fuels with a fossil origin (Amyris 2013). According to the company's $\mathrm{CEO}$, in order for scaled production of their products to become feasible, there would be no other place in the world with technology to match that developed in Brazil (Herzog 2010), which could also provide a good environment to test innovative technologies for biodiesel production.

It is important to note that if Brazil used ethanol for biodiesel production, the quality of biodiesel produced meets biodiesel ASTM International quality specifications, and that Brazil has equipment manufacturers that offer biodiesel plants designed to operate using either the ethylic or methylic route (Olivério 2006).

Figure 6 depicts the biodiesel process production using methanol and ethanol.

\subsection{Development of technology for biodiesel production in Brazil}

According to Howarth et al. (2009), much of the current interest worldwide is focused on the second generation of biofuels, which are intended to enhance or replace the transesterification process to produce biodiesel. In this context, Searchinger (2009) states that government subsidies are important in order to stimulate the development of biofuels. Similarly, Dermibas (2009) notes that reducing technological, economical, supply, storage, safety and policy barriers to the development of biofuels is one of the driving factors in the Governments' involvement in biofuel research and development. Nevertheless, it seems that the Brazilian Government has not been supporting efficiently the development of new technology or innovation for biodiesel production.

In an investigation carried out on calls for projects for biofuels development performed by the FINEP, only two specific calls regarding biodiesel production were found: one in 
2005 and one in 2006. From the 15 projects selected in these calls, none of them was related to the biodiesel production process, which is striking given the existence of investments for the technological development of biodiesel but no interest from the industry (FINEP 2014). The lack of response to the calls seems to have led the Government to abandon the idea of developing the ethylic route. Recent legislation, passed in 2014, that establishes rules for biodiesel production in the country, does not even mention ethanol as the alcohol to be used for transesterification reaction. On the other hand, there is reference in the legislation concerning leakage of methanol during delivery, the spillage of methanol in the tank, and fire or the explosion of methanol (Brazil 2014).

With regard to the private sector, Brazil's participation as a technological developer of technology for transesterification is also small. There are few patents in the area of biodiesel production, which makes it necessary to secure investments in order to overcome the technical difficulties (Quintella et al. 2009). Analysis of the 114 patents related to the transesterification process collected in this research until 2013 revealed that only five of them were from companies or inventors residing in Brazil as applicants (Espacenet 2013). Among the top 10 countries in respect of patents application related to transesterification technology, China (19 patents), France (12 patents) and Germany (11 patents) are noteworthy. The number of patents required by China, as the country of the applicant or the inventor, is almost four times the number of Brazil, putting the country into only sixth position, behind China, France, Germany, Japan ( 9 patents) and USA ( 8 patents). The other top 10 countries are: India (3 patents), Republic of Moldova (2 patents), Spain (2 patents) and Czech republic (2 patents).

\section{Final remarks}

In terms of production, Brazil has achieved a major breakthrough in the consolidation of the biodiesel market. The current production of biodiesel is about 4 million cubic meters per year, half of the production capacity. Nonetheless, among the 67 approved production plants in the country, our research showed that the vast majority produce biodiesel using the methylic route, disregarding the availability of ethanol and social and environmental benefits associated with biodiesel production by the ethylic route. The preference for the use of the methylic route in the production of biodiesel could be explained primarily by economic factors, since the cost of production using methanol is lower. Furthermore, the production by the ethylic route still faces problems related to the fact that the technology is still at an early stage.

A company was identified which was producing biodiesel through the ethylic route, using technology developed within the company and articulating its own net of suppliers, making the biodiesel production by ethylic route more attractive even in economic terms. Furthermore, it has been identified in the literature that there have been advances in the study of the ethylic route and the potential of this process for the production of biodiesel. However, it was also found that the government has provided no incentive to use ethanol in biodiesel production and, in general, there is no initiative to develop new technological process within the private sector. Consequently, Brazil needs to import methanol in order to meet PNBN objectives, generating a deficit in the trade balance.

In conclusion, despite some advances, biodiesel production by transesterification reaction in Brazil seems to fail to take account of some environmental and social aspects of sustainability. There is a large capacity to generate ethylic alcohol in the country, but the use of this product as alcohol for biodiesel production has not been encouraged. From a 
strategic point of view, Brazilian dominance in ethylic alcohol production has not yet resulted in adding value to the biodiesel product, leading to the external dependence of methanol and causing deficits in the net trade balance. In this sense, the use of ethanol, even with its technical and economic disadvantages, could be attractive for the country from a strategic and environmental point of view if there was an effort to introduce innovative technology to produce biodiesel through a truly renewable and cleaner supply chain.

Acknowledgments To the reviewers of the paper for the important contributions.

\section{References}

AMYRIS. Breaktrhough science. http://www.amyris.com/Innovation/155/BreakthroughScience. Accessed 15 Oct 2013.

ALICEWEB-Analysis of Foreign Trade Information System. Methanol importation report. http:// aliceweb2.desenvolvimento.gov.br/. Accessed 24 Jan 2014.

ANP_National Agency of Oil, Natural Gas and Biofuels. (2009). Monthly bulletin of biodiesel. http:// www.anp.gov.br/?dw=4895 Accessed 7 Aug 2009.

ANP_National Agency of Oil, Natural Gas and Biofuels. (2011a). Biofuels. http://www.anp.gov.br/?id= 470. Accessed 1 Oct 2011.

ANP - National Agency of Oil, Natural Gas and Biofuels. (2011b). Monthly biodiesel bulletin. http://www. anp.gov.br/?dw=57881. Accessed 5 Oct 2011.

ANP-National Agency of Oil, Natural Gas and Biofuels. (2013). Resolução $N^{\circ}$ 30, de 6 de agosto de. Construction, capacity expansion, modification and operation of biodiesel plant production in Brazil. http://nxt.anp.gov.br/NXT/gateway.dll/leg/resolucoes_anp/2013/agosto/ranp\%2030\%20-\%202013.xml. Accessed 01 Nov 2013.

ANP - National Agency of Oil, Natural Gas and Biofuels. Monthly statistic data. http://www.anp.gov.br/ ?id=548. Accessed 23 Jan 2014.

Basha, S. A., Gopal, K. R., \& Jebaraj, S. (2009). A review on biodiesel production, combustion, emissions and performance. Renewable and Sustainable Energy Reviews, 13, 1628-1634.

BIODIESELBR. Alcohol: The market for methanol. http://www.biodieselbr.com/revista/022/mercadometanol-1.htm. Accessed 23 Oct 2014.

BNDES-National Bank of Economic and Social Development. Forming a biodiesel market in Brazil. http://www.bndes.gov.br/conhecimento/bnset/set2502.pdf. Accessed 1 July 2008.

Boog, J. H. F., Silveira, E. L. C., de Caland, L. B., \& Tubino, M. (2011). Determining the residual alcohol in biodiesel through its flash point. Fuel, 90, 905-907.

Brasil Law. (2005). $\mathrm{n}^{\circ}$ 11.097, 13 January 2005. Introduction of biodiesel into Brazilian energy matrix.

Brasil Law. CAMEX reduces import rate of methanol. http://www.brasil.gov.br/economia-e-emprego/2013/ 10/camex-reduz-aliquota-do-imposto-de-importacao-de-metanol Accessed 23 Jan 2014.

BRASIL. Law. Government establishes addition of $27 \%$ ethanol in gasoline. http://www.brasil.gov.br/ economia-e-emprego/2015/03/adicao-de-27-de-etanol-na-gasolina-e-estabelecida-pelo-governo. Accessed 27 Aug 2015.

Castanheira, É. G., Grisoli, R., Freire, F., Pecora, V., \& Coelho, S. T. (2014). Environmental sustainability of biodiesel in Brazil. Energy Policy, 65, 680-691.

da Rós, P. C. M., Silva, W. C., Grabauskas, D., Perez, V. H., \& de Castro, H. F. (2014). Biodiesel from babassu oil: Characterization of the product obtained by enzymatic route accelerated by microwave irradiation. Industrial Crops and Products, 52, 313-320.

Demirbas, A. (2005). Biodiesel production from vegetable oils via catalytic and non-catalytic supercritical methanol transesterification methods. Progress in Energy and Combustion Science, 31, 466-487.

Demirbas, A. (2008). Biofuels sources, biofuel policy, biofuel economy and global biofuel projections. Energy Conversion and Management, 49(8), 2106-2116.

Demirbas, M. F. (2009). Biorefineries for biofuel upgrading: A critical review. Applied Energy, 86, S151S161.

EIA-U.S. Energy Information Administration. Real prices viewer. http://www.eia.gov/forecasts/steo/ realprices/. Accessed 30 Oct 2014.

ESPACENET. Patent Search. http://www.epo.org/searching/free/espacenet.html. Accessed 1 July 2013. 
EU-European Union. Regulation (EC) No 1272/2008 of the European Parliament and of the council of 16 December 2008 on classification, labelling and packaging of substances and mixtures, amending and repealing directives 67/548/EEC and 1999/45/EC, and amending regulation (EC) No 1907/2006. http:// eur-lex.europa.eu/LexUriServ/LexUriServ.do?uri=OJ:L:2008:353:0001:1355:EN:PDF. Accessed 14 Sept 2015.

FERTIBOM. Biodiesel biomax. http://www.fertibom.com.br. Accessed 1 July 2015.

FINEP. Innovation on the Agenda. Fertibom makes $100 \%$ renewable biodiesel with its own technology. http://www.finep.gov.br/images/revistas-finep/edicao-789/index.html\#p=45. Accessed 30 Aug 2015.

Frenia, M. L., \& Schauben, J. L. (1993). Methanol inhalation toxicity. Annals of Emergency Medicine, 22, 1919-1923.

Garcez, C. A. G., \& de Souza Vianna, J. N. (2009). Brazilian biodiesel policy: Social and environmental considerations of sustainability. Energy, 34, 645-654.

Garcia, L. F., Conejero, M. A., Neves, M. F. (2007). Biodiesel: Conjecture based on the 30 years of proalcohol. XLV SOBER congress: Knowledge for future farming, Londrina. http://www.sober.org.br/ palestra/6/852.pdf. Accessed 1 July 2015.

Girard, P., Fallot, A. (2006). Review of existing and emerging technologies for the production of biofuels in developing countries. Energy for Sustainable Development, 10(2), 92-108.

Gui, M. M., Lee, K. T., \& Bhatia, S. (2009). Supercritical ethanol technology for the production of biodiesel: Process optimization studies. The Journal of Supercritical Fluids, 49(2), 286-292.

Haas, M. J., McALOON, A. J., Yee, W. C., \& Foglia, T. A. (2006). A process model to estimate biodiesel production costs. Bioresource Technology, 97(4), 671-678.

Hall, J., Matos, S., Severino, L., \& Beltrão, N. (2009). Brazilian biofuels and social exclusion: Established and concentrated ethanol versus emerging and dispersed biodiesel. Journal of Cleaner Production, 17, $77-85$.

Herzog, A. L. (2010). Amyris, a mill of innovation. Revista EXAME. http://exame.abril.com.br/economia/ meio-ambiente-e-energia/noticias/amyris-usina-inovacoes-534451.

Howarth, R.W., Bringezu, S., Bekunda, M., Fraiture, C., Maene, L., Martinelli, L., Sala, O. (2009). Rapid assessment on biofuels and the environment: Overview and key findings. In R. W. Howarth, \& S. Bringezu. Biofuels: Environmental consequences and interactions with changing land use proceedings of the scientific committee on problems of the environment (SCOPE). International Biofuels Project Rapid Assessment. http://cip.cornell.edu/DPubS?service=UI\&version=1.0\&verb=Display\&handle= scope. Accessed 1 July 2015.

Janaun, J., \& Ellis, N. (2010). Perspectives on biodiesel as a sustainable fuel. Renewable and Sustainable Energy Reviews, 14, 1312-1320.

Janssen, R., \& Rutz, D. D. (2011). Sustainability of biofuels in Latin America: Risks and opportunities. Energy Policy, 39(10), 5717-5725.

Jayed, M. H., Masjuki, H. H., Saidur, R., Kalam, M. A., \& Jahirul, M. I. (2009). Environmental aspects and challenges of oilseed produced biodiesel in Southeast Asia. Renewable and Sustainable Energy Reviews, 13(9), 2452-2462.

Kaercher, J. A., Schneider, R. C. S., Klamt, R. A., Silva, W. L. T., Schmatz, W. L., Szarblewski, M. S., \& Machado, E. L. (2013). Optimization of biodiesel production for self-consumption: Considering its environmental impacts. Journal of Cleaner Production, 46, 74-82.

Kanitkar, A., Balasubramanian, S., Lima, M., \& Boldor, D. (2011). A critical comparison of methyl and ethyl esters production from soybean and rice bran oil in the presence of microwaves. Bioresource Technology, 102, 7896-7902.

Kaur, N., \& Ali, A. (2015). Biodiesel production via ethanolysis of jatropha oil using molybdenum impregnated calcium oxide as solid catalyst. RSC Advances, 5(18), 13285-13295.

Khalil, C. N. O. (2006). The technologies for the Biodiesel production. In: J. R. Ferreira, (Coord.) \& C. M. P. Neves Cristo (Eds.), Futuro da Indústria: Biodiesel. Brasília: MDIC-STI/IEL.

LA Rovere, E. L., Pereira, A. S., \& Simões, A. F. (2011). Biofuels and sustainable energy development in Brazil. World Development, 39, 1026-1036.

Leoneti, A. B., Aragao-Leoneti, V., \& de Oliveira, S. V. W. B. (2012). Glycerol as a by-product of biodiesel production in Brazil: Alternatives for the use of unrefined glycerol. Renewable Energy, 45, 138-145.

Lima, P. C. R. (2004). Biodiesel and social inclusion. Consultoria Legislativa da Câmara dos Deputados. http://www2.camara.gov.br/publicacoes/estnottec/tema16. Accessed 7 July 2009.

Lôbo, I. P., Ferreira, S. L. C., \& Cruz, R. S. (2009). Biodiesel: Quality parameters and analytical methods. Química Nova, 32, 1596-1608.

Ma, F., \& Hanna, M. A. (1999). Biodiesel production: a review. Bioresource technology, 70(1), 1-15.

Marchetti, J. M., Miguel, V. U., \& Errazu, A. F. (2007). Possible methods for biodiesel production. Renewable and Sustainable Energy Reviews, 11(6), 1300-1311. 
Mcbride, A. C., Dale, V. H., Baskaran, L. M., Downing, M. E., Eaton, L. M., Efroymson, R. A., \& Storey, J. M. (2011). Indicators to support environmental sustainability of bioenergy systems. Ecological Indicators, 11(5), 1277-1289.

MDIC-Ministry of Development, Industry and Foreign Trade. Camex extending reduction of import duty for methanol. http://www.mdic.gov.br/sitio/interna/noticia.php?area=1\&noticia=13047. Accessed 10 July 2014.

Meher, L. C., Sagar, D. V., \& Naik, S. N. (2006). Technical aspects of biodiesel production by transesterification-a review. Renewable and Sustainable Energy Reviews, 10, 248-268.

Mendow, G., \& Querini, C. A. (2013). High performance purification process of methyl and ethyl esters produced by transesterification. Chemical Engineering Journal, 228, 93-101.

Mendow, G., Veizaga, N. S., Sánchez, B. S., \& Querini, C. A. (2012). Biodiesel production by two-stage transesterification with ethanol by washing with neutral water and water saturated with carbon dioxide. Bioresource Technology, 118, 598-602.

Nogueira, L. A. H. (2011). Does biodiesel make sense? Energy, 36, 3659-3666.

Olah, G. A. (2005). Beyond oil and gas: The methanol economy. Angewandte Chemie International, 44, 2636-2639.

Olivério, J. L. (2006). The Brazilian biodiesel program in view of equipment industry. In: J. R. Ferreira (Coord.), C. M. P. Neves Cristo (Eds.), Futuro da Indústria: Biodiesel. Brasília: MDIC-STI/IEL.

Parente, E. J. S. (2003). Biodiesel: A technology adventure in a funny country (Biodiesel: Uma aventura tecnológica num país engraçado) (p. 66). Fortaleza: Tecbio.

Pedersen, A. T., Nordblad, M., Nielsen, P. M., \& Woodley, J. M. (2014). Batch production of FAEEbiodiesel using a liquid lipase formulation. Journal of Molecular Catalysis B: Enzymatic, 105, 89-94.

Pereira, P. A., \& Andrade, J. B. (1998). Sources reactivity and quantification of atmospheric methanol and ethanol. Química Nova, 21, 744-754.

Quintella, C. M., Teixeira, L. S. G., Korn, M. G. A., Costa Neto, P. R., Torres, E. A., Castro, M. P., \& Jesus, C. A. C. (2009). Biodiesel chain from the lab bench to the industry: An overview with technology assessment, R\&D\&I opportunities and tasks. Química Nova, 32, 793-808.

Rathmann, R., Szklo, A., \& Schaeffer, R. (2012). Targets and results of the Brazilian biodiesel incentive program-has it reached the promised land? Applied Energy, 97, 91-100.

Renó, M. L. G., Lora, E. E. S., Palacio, J. C. E., Venturini, O. J., Buchgeister, J., \& Almazan, O. (2011). A LCA (life cycle assessment) of the methanol production from sugarcane bagasse. Energy, 36, 3716-3726.

Sanli, H., \& Canakci, M. (2008). Effects of different alcohol and catalyst usage on biodiesel production from different vegetable oils. Energy \& Fuels, 22, 2713-2719.

Searchinger, T. D. (2009). Government policies \& drivers of world biofuels, sustainability criteria, certification proposals \& their limitations. In R. W. Howarth, \& S. Bringezu (Eds.), Biofuels: Environmental consequences and interactions with changing land use proceedings of the scientific committee on problems of the environment (SCOPE). International Biofuels Project Rapid Assessment. http://cip. cornell.edu/DPubS? service=UI\&version=1.0\&verb=Display\&handle=scope. Accessed 1 July 2015.

Sheehan, J., Camobreco, V., Duffield, J., Graboski, M., Shapouri, H. (1998). An overview of biodiesel and petroleum diesel life cycles. National Renewable Energy Laboratory, U.S. Department of Energy. http://www.nrel.gov/docs/legosti/fy98/24772.pdf. Accessed 1 Nov 2015.

SIDRA-IBGE Auto Recovery System. Table of Production and sales of products and/or industry services, according to the classes of activities and products-CNAE 2021. http://www.sidra.ibge.gov.br/bda/ tabela/listabl.asp?c=3465\&z=t\&o=28. Accessed 24 Jan 2014.

Stamenkovic, O. S., VeličKovic, V., \& Veljkovic, V. B. (2011). The production of biodiesel from vegetable oils by ethanolysis: Current state and perspectives. Fuel, 90, 3141-3155.

Stattman, S. L., Hospes, O., \& Mol, A. P. J. (2013). Governing biofuels in Brazil: A comparison of ethanol and biodiesel policies. Energy Policy, 61, 22-30.

Vieitez, I., da Silva, C., Alckmin, I., Borges, G. R., Corazza, F. C., Oliveira, J. V., \& Jachmanián, I. (2008). Effect of temperature on the continuous synthesis of soybean esters under supercritical ethanol. Energy \& Fuels, 23(1), 558-563.

Yusoff, M. F. M., Xu, X., \& Guo, Z. (2014). Comparison of fatty acid methyl and ethyl esters as biodiesel base stock: A review on processing and production requirements. Journal of the American Oil Chemists' Society, 91(4), 525-531. 